Article

\title{
Synthesis and Anti-Inflammatory Activities of Phloroglucinol-Based Derivatives
}

\author{
Ning Li ${ }^{1,2}$, Shabana I. Khan ${ }^{1,3}$, Shi Qiu ${ }^{1}$ and Xing-Cong $\mathrm{Li}^{1,3, *(1)}$ \\ 1 Nation Center for Natural Products Research, Research Institute of Pharmaceutical Sciences, \\ School of Pharmacy, The University of Mississippi, University, MS 38677, USA; ahmulining@163.com (N.L.); \\ skhan@olemiss.edu (S.I.K.); sqiu@olemiss.edu (S.Q.) \\ 2 School of Pharmacy, Anhui Medical University, Hefei 230032, China \\ 3 Department of Biomolecular Sciences, School of Pharmacy, The University of Mississippi, University, \\ MS 38677, USA \\ * Correspondence: xcli7@olemiss.edu; Tel.: +1-662-915-6742
}

Received: 7 November 2018; Accepted: 3 December 2018; Published: 7 December 2018

check for updates

\begin{abstract}
The natural product phloroglucinol-based derivatives representing monoacyl-, diacyl-, dimeric acyl-, alkylated monoacyl-, and the nitrogen-containing alkylated monoacylphloro- glucinols were synthesized and evaluated for inhibitory activities against the inflammatory mediators such as inducible nitric oxide synthase (iNOS) and nuclear factor kappaB (NF-kB). The diacylphloroglucinol compound 2 and the alkylated acylphloroglucinol compound 4 inhibited iNOS with IC $_{50}$ values of 19.0 and $19.5 \mu \mathrm{M}$, respectively, and NF- $\mathrm{KB}$ with $\mathrm{IC}_{50}$ values of 34.0 and $37.5 \mu \mathrm{M}$, respectively. These compounds may serve as leads for the synthesis of more potent anti-inflammatory compounds for future drug discovery.
\end{abstract}

Keywords: phlorogluciniol; acylphloroglucinol; anti-inflammatory; iNOS; NF-kB

\section{Introduction}

The natural product phloroglucinol (1) and its derivatives have found a wide range of applications as pharmaceuticals, cosmetics, textiles, paints, and dyes due to their diverse biological activities [1,2]. More than 700 naturally occurring phloroglucinol derivatives have been reported, of which acylphloroglucinol derivatives comprise the largest group [1,3]. Structurally fascinating acylphloroglucinols possess antidepressant, antimicrobial, antiviral, antitumor, antioxidant, and anti-inflammatory activities [4-7]. The synthetic antispasmodic drug flopropione (3-propionylphloroglucinol) is a representative of this chemical class [8,9].

The anti-inflammatory activity of the naturally occurring phloroglucinol derivatives acting on diverse molecular targets has drawn our particular attention. For example, complex phlorotannins from edible brown algae showed strong inhibitory effects on nitric oxide (NO) production in lipopolysaccharide (LPS)-induced RAW 264.7 macrophage cells [10]. Purified oligomeric phlorotannins containing fucodiphlorethol A, tetraphlorethol B, tetrafucol A, tetraisofuhalol, and phlorofucofuroeckol A (Figure 1) also demonstrated the ability to inhibit NO production and suppressing iNOS and cyclooxygenase (COX)-2 [11]. The acylphloroglucinol hyperforin (Figure 1) from St. John's wort suppressed prostaglandin $\mathrm{E}_{2}$ formation in vitro and in vivo through inhibition of microsomal $\mathrm{PGE}_{2}$ synthase-1 [12]. 2-Acetyl-4-geranylphloroglucinol (Figure 1) isolated from the Rutaceaous plant Melicope ptelefolia is a strong dual inhibitor of 5-lipoxygenase (LOX) and COX-2 [13]. 2,4-Diacetylphloroglucinol (2) (Figure 1), a microbial metabolite of Pseudomonas aeruginosa, exhibited antimetastatic activity by mediating inhibition of reactive oxygen species (ROS), nuclear factor kappaB (NF-kB), B-cell lymphoma 2 (Bcl-2), matrix metalloproteinase-2 (MMP-2), vascular endothelial growth 
factor (VEGF) and primary inflammatory mediators such as tumor necrosis factor (TNF)- $\alpha$, interleukin (IL)-6, IL-1 $\beta$ and NO [14]. In an effort to identify synthetically available phloroglucinol-based anti-inflammatory compounds, we synthesized several acylphloroglucinols and evaluated their iNOS and NF- $\mathrm{kB}$ inhibitory activities.

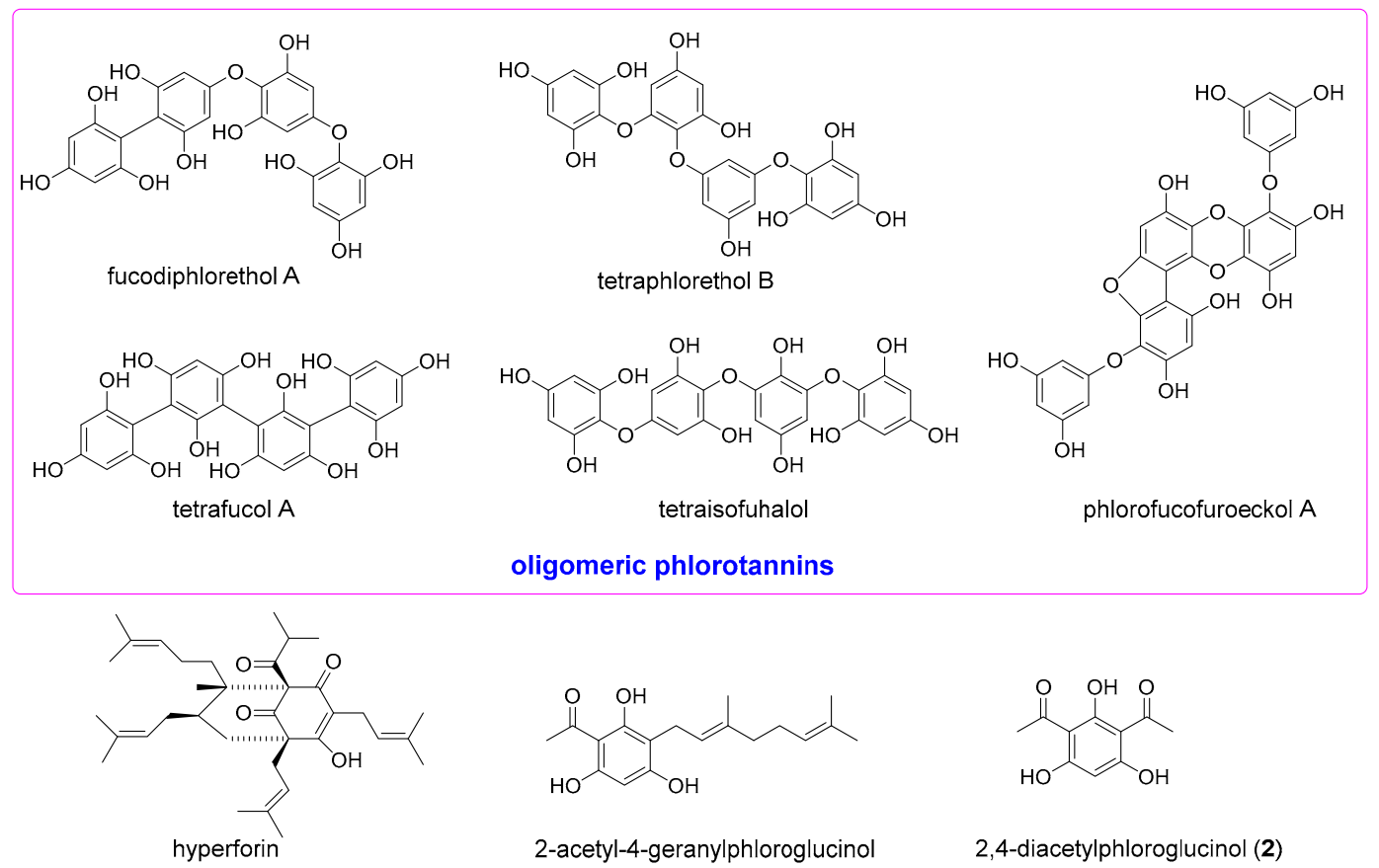

Figure 1. Representative phloroglucinol derivatives with anti-inflammatory activities.

\section{Results and Discussion}

Based on the concept that both natural and synthetic acylphloroglucinols possess potent biological activities [6,7,13-17], seven compounds representing monoacyl-, diacyl-, dimeric acyl-, alkylated monoacyl-, and the nitrogen-containing alkylated monoacylphloroglucinols were synthesized (Scheme 1). Diacylphloroglucinol (2) and monoacylphloroglucinol (3) were prepared first according to the procedures described previously [18-20]. Using $\mathbf{3}$ as a starting material, compounds 4 and $\mathbf{6}$ were synthesized, respectively, in a one-step reaction adapted from a previously reported procedure [17]. Blocking the two non-hydrogen bonding hydroxyl groups in 4 using $\mathrm{MOMCl}$ afforded compound 5. This synthesis was intended to assess the role of the hydroxyl groups on the phloroglucinol ring for activity. The nitrogen-containing compound 7 was designed to alter chemical nature of the target molecule based on previous reports [21-23]. It was synthesized by reacting 3 with 1-(4-(bromomethyl)benzyl)-piperidine that was prepared from commercially available piperidine and $p$-xylylene dibromide in the presence of $\mathrm{CH}_{2} \mathrm{Cl}_{2}$ and $\mathrm{K}_{2} \mathrm{CO}_{3}$. As can be seen from Scheme 1, the reaction conditions for the synthesis of these compounds were mild as all the reactions were conducted at room temperature.

The identification of all the synthetic compounds was achieved by interpretation of NMR and MS data. Compounds 4-7 have not been reported prior to this study. It was noted that compound 7 produced an unusual ${ }^{1} \mathrm{H}-\mathrm{NMR}$ spectrum in $\mathrm{CD}_{3} \mathrm{OD}$, displaying two sets of ${ }^{1} \mathrm{H}-\mathrm{NMR}$ signals in a ratio of approximately 1.5:1 associated with the para-substituted phenyl ring and some protons of the piperidine ring (Supplementary Materials). However, when the compound was measured in $\mathrm{CDCl}_{3}$ (with poor solubility), a single set of ${ }^{1} \mathrm{H}-\mathrm{NMR}$ signals appeared. Use of the weakly basic NMR solvent $\mathrm{C}_{5} \mathrm{D}_{5} \mathrm{~N}$ afforded a ${ }^{1} \mathrm{H}-\mathrm{NMR}$ spectrum showing two sets of signals in a ratio of approximately $4: 1$ for the aromatic protons of the phenyl ring and the methylene attached to the piperidine ring. This interesting phenomenon can be explained by the fact that compound 7 is, to some extent, a zwitterionic molecule 
due to the presence of the acidic phenolic hydroxyl group on the phloroglucinol core and the basic amine functionality on the side chain. While $\mathrm{CD}_{3} \mathrm{OD}$ can strongly induce the protonation/deuteriation of the nitrogen atom, $\mathrm{C}_{5} \mathrm{D}_{5} \mathrm{~N}$ has the ability to facilitate the formulation of a zwitterion, thereby resulting in the presence of an additional set of NMR signals. The ${ }^{1} \mathrm{H}$ - and ${ }^{13} \mathrm{C}-\mathrm{NMR}$ signals of 7 in $\mathrm{C}_{5} \mathrm{D}_{5} \mathrm{~N}$ were unequivocally assigned using $2 \mathrm{D} \mathrm{NMR}$ of ${ }^{1} \mathrm{H}_{-}{ }^{1} \mathrm{H}$ correlation spectroscopy (COSY), heteronuclear single quantum coherence (HSQC) and hetero- nuclear multiple bond correlation (HMBC) experiments.

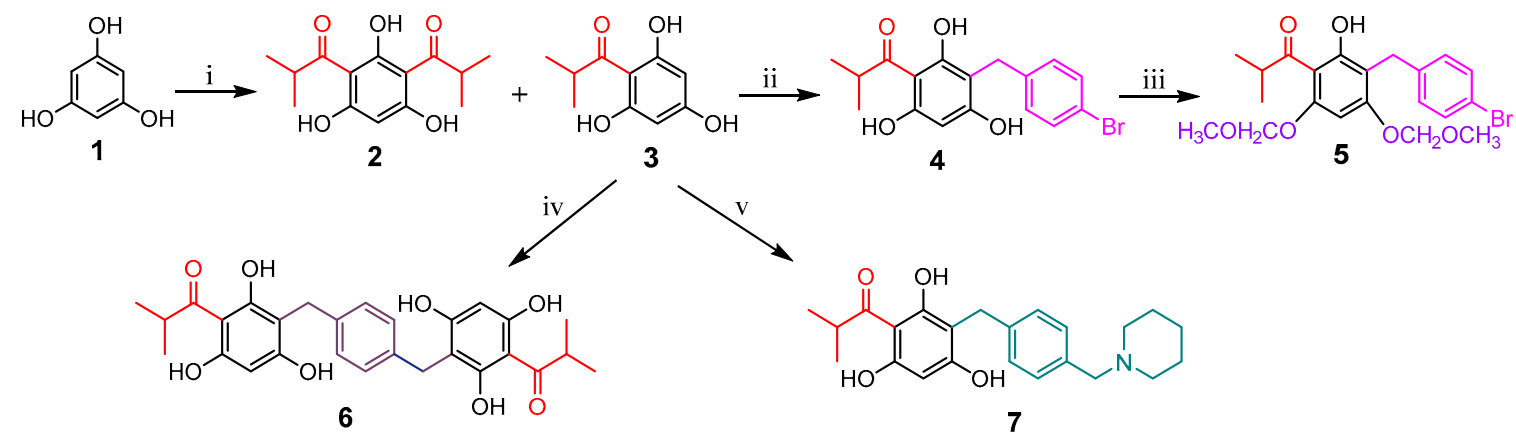

Scheme 1. Synthesis of compounds 2-7. Reagents and conditions: (i) nitrobenzene, $\mathrm{AlCl}_{3}, \mathrm{rt}$ for $0.5 \mathrm{~h}$, then isobutyryl chloride, $65{ }^{\circ} \mathrm{C}$ for $21 \mathrm{~h}$; (ii) $\mathrm{NaOH}, \mathrm{H}_{2} \mathrm{O}$, TBAI, 1-bromo-4-(bromomethyl)benzene, hexane, rt for $48 \mathrm{~h}$; (iii) acetone, $\mathrm{K}_{2} \mathrm{CO}_{3}, \mathrm{CH}_{3} \mathrm{OCH}_{2} \mathrm{Cl}$, rt for $24 \mathrm{~h}$; (iv) $\mathrm{NaOH}, \mathrm{H}_{2} \mathrm{O}$, TBAI, $p$-xylylene dibromide, toluene, rt for $6 \mathrm{~h}$; (v) piperidine, $\mathrm{CH}_{2} \mathrm{Cl}_{2}, \mathrm{~K}_{2} \mathrm{CO}_{3}$, $p$-xylylene dibromide, $\mathrm{NaOH}, \mathrm{H}_{2} \mathrm{O}$, $\mathrm{MeOH}, \mathrm{rt}$ for $7 \mathrm{~h}$.

In vitro anti-inflammatory testing of compounds $2-7$ was conducted by assessing the inhibition of iNOS in LPS-induced macrophages (RAW 264.7) and inhibition of NF- $\mathrm{kB}$ in phorbol 12-myristate 13-acetate (PMA)-induced human chondrosarcoma cells (SW1353). As shown in Table 1, diacylphloroglucinol compound 2 showed the best activity, inhibiting iNOS and NF- $\mathrm{kB}$ with $\mathrm{IC}_{50}$ values of 19.0 and $34.0 \mu \mathrm{M}$, respectively, compared with the positive control parthenolide with $\mathrm{IC}_{50}$ values of 2.5 and $20.5 \mu \mathrm{M}$, respectively. The activity of alkylated acylphloroglucinol 4 against these two targets ( $\mathrm{IC}_{50} 19.5$ and $37.5 \mu \mathrm{M}$, respectively) was also very similar to compound 2 . When the hydroxyl groups in 4 were protected leading to compound 5 , iNOS inhibitory activity was decreased $\left(\mathrm{IC}_{50}\right.$, $50 \mu \mathrm{M}$ ) while NF- $\mathrm{kB}$ activity was slightly increased $\left(\mathrm{IC}_{50}, 29.0 \mu \mathrm{M}\right)$. This suggests these two hydroxyl groups play a role for the activity and the differential activity between the two compounds may be associated with molecular lipophilicity. Dimeric acylphloroglucinol 6 inhibited iNOS to a similar extent $\left(\mathrm{IC}_{50}, 19.0 \mu \mathrm{M}\right)$ but inhibition of NF- $\mathrm{kB}$ was weaker $\left(\mathrm{IC}_{50}, 85.0 \mu \mathrm{M}\right)$. The nitrogen- containing compound 7 was only moderately inhibiting iNOS with an $\mathrm{IC}_{50}$ value of $49.0 \mu \mathrm{M}$, indicating the introduction of the amino group in this chemotype is not helpful. On the other hand, monoacylphloroglucinol 3 was only marginally inhibiting NF- $\mathrm{kB}$ with an $\mathrm{IC}_{50}$ value of $90.0 \mu \mathrm{M}$, indicating that additional acylation or alkylation on the phloroglucinol ring is necessary to enhance anti-inflammatory activity. Cytotoxicity testing using African monkey kidney fibroblast cell line (Vero) showed that compounds 2-7 were not cytotoxic up to a concentration of $50 \mu \mathrm{M}$

The anti-inflammatory activity observed for compound 2 against iNOS and NF- $\mathrm{kB}$ appears to be consistent with the previously reported data for the analogue 2,4-diacetylphloroglucinol [13]. Compound 2 was previously reported to possess potent in vitro antifungal activity against Cryptococcus neoformans [17]. An enhanced inflammatory cell response in C. neoformans infection has been observed via regulation of IL-23 and IL-12 [24]. Our findings suggest that the anti-inflammatory activity of compound 2 targeting iNOS and NF- $\mathrm{KB}$ would have a positive impact on its antifungal activity. 
Table 1. Anti-inflammatory activity of synthetic acylphloroglucinols.

\begin{tabular}{ccc}
\hline \multirow{2}{*}{ Compound } & iNOS Inhibition & NF-кB Inhibition \\
\cline { 2 - 3 } & $\left.\mathbf{I C}_{\mathbf{5 0}}, \boldsymbol{\mu M}\right)$ & $\mathbf{I C}_{\mathbf{5 0}, \boldsymbol{\mu M})}$ \\
\hline $\mathbf{2}$ & $19.0 \pm 1.4$ & $34.0 \pm 8.5$ \\
$\mathbf{3}$ & $\mathrm{NA}$ & $90.0 \pm 14.1$ \\
$\mathbf{4}$ & $19.5 \pm 0.7$ & $37.5 \pm 3.5$ \\
$\mathbf{5}$ & $50.0 \pm 0$ & $29.0 \pm 15.5$ \\
$\mathbf{6}$ & $19.0 \pm 1.4$ & $85.0 \pm 21.2$ \\
$\mathbf{7}$ & $49.0 \pm 1.4$ & $\mathrm{NA}$ \\
Parthenolide & $2.5 \pm 0.2$ & $20.5 \pm 2.9$ \\
\hline
\end{tabular}

NA, not active at $50 \mu \mathrm{M}$ for iNOS and $100 \mu \mathrm{M}$ for NF-kB.

In conclusion, the natural product phloroglucinol-derived compounds were synthesized and evaluated for anti-inflammatory activity against iNOS and NF-KB as well as cytotoxicity against the mammalian Vero cells. This exploratory study has generated meaningful structure activity relationship information from the limited number of synthetic compounds. The diacylphloroglucinol compound 2 and the alkylated monoacylphloroglucinol compound 4 are dual inhibitors of iNOS and NF- $\mathrm{kB}$. Further synthesis of these two chemotypes of compounds may afford compounds with improved anti-inflammatory activities which could be better candidates for future drug discovery.

\section{Materials and Methods}

\subsection{General Experimental Procedures}

The nuclear magnetic resonance (NMR) spectra using standard pulse programs were recorded at room temperature on a BrukerAvance DPX-400 spectrometer (Bruker, Billerica, MA, USA) operating at $400\left({ }^{1} \mathrm{H}\right)$ and $100\left({ }^{13} \mathrm{C}\right) \mathrm{MHz}$. The chemical shift $(\delta, \mathrm{ppm})$ values were calibrated using the residual NMR solvent and coupling constant $(J)$ was reported in Herts $(\mathrm{Hz})$. High-resolution time-of-flight mass spectrometry (TOF-MS) and electrospray ionisation mass spectrometry (ESI-MS) were measured on an Agilent series 1100 SL spectrometer (Agilent Technologies, Santa Clara, CA, USA) equipped with an ESI source. Thin layer chromatography (TLC) was performed on silica gel aluminum sheets (silica gel 60 F254, Merck, Darmstadt, Germany) and visualized by UV $254 \mathrm{~nm}$ and spraying $10 \% \mathrm{H}_{2} \mathrm{SO}_{4}$ followed by heating. Column chromatography was done on normal-phase silica gel $(230 \times 400$ mesh, J. T. Baker, Center Valley, PA, USA) and Sephadex LH-20 (75 $\mu \mathrm{m}$, GE Healthcare Bio-Sciences $\mathrm{AB}$, Uppsala, Sweden). Reactants and reagents including anhydrous phloroglucinol, nitrobenzene, aluminum chloride $\left(\mathrm{AlCl}_{3}\right)$, n-butyl ammonium iodide (TBAI), 1-bromo-4-bromomethyl-benzene, chloromethoxymethane $\left(\mathrm{CH}_{3} \mathrm{OCH}_{2} \mathrm{Cl}\right)$, toluene, and piperidine were purchased from Sigma-Aldrich (St. Louis, MO, USA) in appropriate grades and were used without further purification. The yield of each synthetic product after column chromatography is reported. The ${ }^{1} \mathrm{H}$ - and ${ }^{13} \mathrm{C}-\mathrm{NMR}$ assignments for all synthetic products and key intermediates with appropriate numbering systems are shown in the Supplementary Materials. Compounds 2 and $\mathbf{3}$ were synthesized according to the protocols described previously [18-20] and their identification was made by comparison of their NMR spectroscopic data (see Supplementary Materials) with those reported in the literature [17].

\subsection{Synthesis of Compound 4}

To a solution of compound 3 ( $3.0 \mathrm{~g}), \mathrm{NaOH}(1.01 \mathrm{~g})$, and TBAI (catalyzer, $500 \mathrm{mg}$ ) in $\mathrm{H}_{2} \mathrm{O}(225 \mathrm{~mL}$ ) was added 1-bromo-4-(bromomethyl)benzene $(2.5 \mathrm{~g})$ in hexane $(20 \mathrm{~mL})$ dropwise. The mixture was stirred at room temperature for $48 \mathrm{~h}$. The precipitated crude product was collected by filtration. The residue was purified by chromatography on silica gel using acetone:hexane (1:2) to afford $4(1.67 \mathrm{~g}$, yield $30.0 \%$ ). 
1-[3-(4-Bromo-benzyl)-2,4,6-trihydroxy-phenyl]-2-methyl-propan-1-one (4). $\quad{ }^{1} \mathrm{H}-\mathrm{NMR} \quad(400 \mathrm{MHz}$, $\left.\mathrm{CD}_{3} \mathrm{COCD}_{3}\right)$ 8: $14.33(\mathrm{~s}, \mathrm{OH}), 7.35\left(2 \mathrm{H}, \mathrm{d}, J=8.2 \mathrm{~Hz}, \mathrm{H}-14,14^{\prime}\right), 7.24\left(2 \mathrm{H}, \mathrm{d}, J=8.2 \mathrm{~Hz}, \mathrm{H}-13,13^{\prime}\right), 6.16$ $(1 \mathrm{H}, \mathrm{s}, \mathrm{H}-4), 3.99(1 \mathrm{H}, \mathrm{m}, \mathrm{H}-8), 3.85(2 \mathrm{H}, \mathrm{s}, \mathrm{H}-11), 1.13(6 \mathrm{H}, \mathrm{d}, J=6.6 \mathrm{~Hz}, \mathrm{H}-9,10) .{ }^{13} \mathrm{C}-\mathrm{NMR}(100 \mathrm{MHz}$, $\mathrm{CD}_{3} \mathrm{COCD}_{3}$ ) 8: 211.0 (C-7), 165.7 (C-1), 162.8 (C-5), 160.7 (C-3), 142.4 (C-12), 131.6 (C-14, 14'), 131.5 (C-13, 13'), 119.4 (C-15), 107.3 (C-6), 104.2 (C-2), 95.2 (C-4), 39.5 (C-8), 28.0 (C-11), 19.6 (C-9, 10). MS ESI- $(-) m / z=363.0 / 365.2[\mathrm{M}-\mathrm{H}]^{-}$for $\mathrm{C}_{17} \mathrm{H}_{17} \mathrm{BrO}_{4}$.

\subsection{Synthesis of Compound 5}

A suspension of compound $4(346 \mathrm{mg})$ and $\mathrm{K}_{2} \mathrm{CO}_{3}(2.76 \mathrm{~g})$ in acetone $(35 \mathrm{~mL})$ was stirred for $30 \mathrm{~min}$, then $\mathrm{CH}_{3} \mathrm{OCH}_{2} \mathrm{Cl}(480 \mathrm{mg})$ was added. After stirring at room temperature for $48 \mathrm{~h}$, the reaction mixture was filtered. The filtrate was concentrated, and the residue was purified by chromatography on silica gel with acetone:hexane (1:12) to give 5 ( $239 \mathrm{mg}$, yield $52.8 \%)$.

1-[3-(4-Bromo-benzyl)-2-hydroxy-4,6-bis-methoxymethoxy-phenyl]-2-methyl-propan-1-one (5). ${ }^{1} \mathrm{H}-\mathrm{NMR}(400$ $\left.\mathrm{MHz}^{\mathrm{CDCl}} \mathrm{CD}_{3}\right) \delta: 14.0(\mathrm{~s}, \mathrm{OH}), 7.35\left(2 \mathrm{H}, \mathrm{d}, J=8.4 \mathrm{~Hz}, \mathrm{H}-14,14^{\prime}\right), 7.21\left(2 \mathrm{H}, \mathrm{d}, J=8.4 \mathrm{~Hz}, \mathrm{H}-13,13^{\prime}\right), 6.46$ $(1 \mathrm{H}, \mathrm{s}, \mathrm{H}-4), 5.28\left(2 \mathrm{H}, \mathrm{s},-\mathrm{OCH}_{2}\right), 5.24\left(1 \mathrm{H}, \mathrm{s},-\mathrm{OCH}_{2}\right), 3.93(2 \mathrm{H}, \mathrm{s}, \mathrm{H}-11), 3.82(1 \mathrm{H}, \mathrm{m}, \mathrm{H}-8), 3.55(3 \mathrm{H}, \mathrm{s}$, $\left.-\mathrm{OCH}_{3}\right), 3.41\left(3 \mathrm{H}, \mathrm{s},-\mathrm{OCH}_{3}\right), 1.21(6 \mathrm{H}, \mathrm{d}, J=6.7 \mathrm{~Hz}, \mathrm{H}-9,10) .{ }^{13} \mathrm{C}-\mathrm{NMR}\left(100 \mathrm{MHz}, \mathrm{CDCl}_{3}\right) \delta: 210.7$ (C-7), 164.0 (C-5), 160.5 (C-1), 158.9 (C-3), 140.6 (C-12), 131.0 (C-14, 14'), 130.4 (C-13, 13'), 119.2 (C-15), $110.7(\mathrm{C}-2), 106.0(\mathrm{C}-4), 94.9\left(-\mathrm{OCH}_{2}\right), 94.0\left(-\mathrm{OCH}_{2}\right), 91.4(\mathrm{C}-6), 56.8\left(-\mathrm{OCH}_{3}\right), 56.5\left(-\mathrm{OCH}_{3}\right), 39.8(\mathrm{C}-8)$, 27.7 (C-11), $19.4(\mathrm{C}-9,10)$. MS ESI- $(-) m / z=451.0 / 453.2[\mathrm{M}-\mathrm{H}]^{-}$for $\mathrm{C}_{21} \mathrm{H}_{25} \mathrm{BrO}_{6}$.

\subsection{Synthesis of Compound $\mathbf{6}$}

A suspension of compound $3(98 \mathrm{mg})$ and $\mathrm{NaOH}(22 \mathrm{mg})$ in $\mathrm{H}_{2} \mathrm{O}(7.5 \mathrm{~mL})$ was stirred about 30-40 min until it became clear. To this solution was added TBAI $(9.8 \mathrm{mg})$ and $p$-xylylene dibromide $(144 \mathrm{mg})$ in toluene $(4.5 \mathrm{~mL})$ dropwise. After stirring at room temperature for $6 \mathrm{~h}$, the reaction mixture was extracted with ethyl acetate (EtOAc) $(3 \times 20 \mathrm{~mL})$. The combined EtOAc layer was concentrated under reduced pressure to afford a residue, which was purified by chromatography on silica gel using acetone:hexane (1:2) to give 6 ( $44 \mathrm{mg}$, yield 17.8\%).

2-Methyl-1-\{2,4,6-trihydroxy-3-[4-(2,4,6-trihydroxy-3-isobutyryl-benzyl)-benzyl]-phenyl\}-propan-1-one (6). ${ }^{1} \mathrm{H}-\mathrm{NMR}\left(400 \mathrm{MHz}, \mathrm{CD}_{3} \mathrm{COCD}_{3}\right)$ : $14.19(\mathrm{~s}, \mathrm{OH}), 7.17\left(4 \mathrm{H}, \mathrm{s}, \mathrm{H}-13,13^{\prime}, 14,14^{\prime}\right), 6.10\left(2 \mathrm{H}, \mathrm{s}, \mathrm{H}-4,4^{\prime}\right)$, $4.02\left(2 \mathrm{H}, \mathrm{m}, \mathrm{H}-8,8^{\prime}\right), 3.85\left(4 \mathrm{H}, \mathrm{s}, \mathrm{H}-11,11^{\prime}\right), 1.14\left(12 \mathrm{H}, \mathrm{d}, J=6.8 \mathrm{~Hz}, \mathrm{H}-9,9^{\prime}, 10,10^{\prime}\right) .{ }^{13} \mathrm{C}-\mathrm{NMR}(100$ $\left.\mathrm{MHz}, \mathrm{CD}_{3} \mathrm{COCD}_{3}\right)$ 8: $210.1\left(\mathrm{C}-7,7^{\prime}\right), 164.8\left(\mathrm{C}-1,1^{\prime}\right), 162.0\left(\mathrm{C}-5,5^{\prime}\right), 159.7\left(\mathrm{C}-3,3^{\prime}\right), 138.9\left(\mathrm{C}-12,12^{\prime}\right)$, $128.1\left(\mathrm{C}-13,13^{\prime}, 14,14^{\prime}\right), 107.3\left(\mathrm{C}-6,6^{\prime}\right), 103.4\left(\mathrm{C}-2,2^{\prime}\right), 94.3\left(\mathrm{C}-4,4^{\prime}\right), 38.7\left(\mathrm{C}-8,8^{\prime}\right), 28.5\left(\mathrm{C}-11,11^{\prime}\right), 18.8$ $\left(\mathrm{C}-9,9^{\prime}, 10,10^{\prime}\right)$. MS ESI-(-) $m / z=493.2\left[\mathrm{M}-\mathrm{H}^{-}\right.$for $\mathrm{C}_{28} \mathrm{H}_{30} \mathrm{O}_{8}$.

\subsection{Synthesis of Compound 7}

To a solution of piperidine $(2.55 \mathrm{~g})$ in $\mathrm{CH}_{2} \mathrm{Cl}_{2}(100 \mathrm{~mL})$ was added $\mathrm{K}_{2} \mathrm{CO}_{3}(5.46 \mathrm{~g})$. After stirring at room temperature for $1 \mathrm{~h}, p$-xylenedibromide $(7.86 \mathrm{~g})$ in $\mathrm{CH}_{2} \mathrm{Cl}_{2}(100 \mathrm{~mL})$ was added dropwise, and the reaction continued for $3 \mathrm{~h}$. The reaction mixture was filtered. The filtrate was concentrated under reduced pressure, and the residue was purified by chromatography on silica gel using acetone:hexane (1:7) to yield the intermediate 1-(4-(bromomethyl) benzyl)piperidine $(2.0 \mathrm{~g})$.

To a solution of compound $3(196 \mathrm{mg})$ and $\mathrm{NaOH}(44 \mathrm{mg})$ in $\mathrm{H}_{2} \mathrm{O}(60 \mathrm{~mL})$ was added the intermediate $(707 \mathrm{mg})$ in $\mathrm{MeOH}(40 \mathrm{~mL})$ dropwise. After stirring at room temperature for $4 \mathrm{~h}$, the reaction mixture was extracted with EtOAc $(3 \times 80 \mathrm{~mL})$ and concentrated under reduced pressure. The residue was purified by chromatography on silica gel using $\mathrm{CHCl}_{3}: \mathrm{MeOH}$ :acetone (10:1:1) to yield 7 (35 mg, yield 9.2\%).

2-Methyl-1-[2,4,6-trihydroxy-3-(4-piperidin-1-ylmethyl-benzyl)-phenyl]-propan-1-one (7). ${ }^{1} \mathrm{H}-\mathrm{NMR}(400$ $\left.\mathrm{MHz}, \mathrm{C}_{5} \mathrm{D}_{5} \mathrm{~N}\right) \delta: 7.74\left(2 \mathrm{H}, \mathrm{d}, J=6.0 \mathrm{~Hz}, \mathrm{H}-13,13^{\prime}\right), 7.68\left(2 \mathrm{H}, \mathrm{d}, J=6.0 \mathrm{~Hz}, \mathrm{H}-14,14^{\prime}\right), 6.61(1 \mathrm{H}, \mathrm{s}, \mathrm{H}-4)$, $4.37(2 \mathrm{H}, \mathrm{s}, \mathrm{H}-11), 4.35$ (1H, m, H-8), 4.23 (2H, s, H-16), 2.97 (4H, m, H-17, 17'), 1.77 (4H, m, H-18, 18'), 
$1.29(6 \mathrm{H}, \mathrm{d}, J=6.7 \mathrm{~Hz}, \mathrm{H}-9,10), 1.28(2 \mathrm{H}, \mathrm{m}, \mathrm{H}-19) .{ }^{13} \mathrm{C}-\mathrm{NMR}\left(100 \mathrm{MHz}, \mathrm{C}_{5} \mathrm{D}_{5} \mathrm{~N}\right) \delta: 211.2(\mathrm{C}-7), 166.4$ (C-1), 164.6 (C-3), 162.5 (C-5), 145.2 (C-12), 132.16 (C-14, 14' ), 130.3 (C-13, 13'), 127.89 (C-15), 107.5 (C-6), 104.8 (C-2), 95.9 (C-4), 61.0 (C-16), 52.99 (C-17, 17'), 39.7 (C-8), 29.2 (C-11), 23.62 (C-18, 18'), 22.78 (C-19), 20.3 (C-9, 10). HRTOF-MS ESI-(+) $m / z=384.2170[\mathrm{M}+\mathrm{H}]^{+}$for $\mathrm{C}_{23} \mathrm{H}_{30} \mathrm{NO}_{4}$ (cal. 384.2176).

${ }^{1} \mathrm{H}-\mathrm{NMR}$ for the isomer of $7\left(400 \mathrm{MHz}, \mathrm{C}_{5} \mathrm{D}_{5} \mathrm{~N}\right) \delta: 7.78\left(2 \mathrm{H}, \mathrm{d}, J=5.8 \mathrm{~Hz}, \mathrm{H}-13,13^{\prime}\right), 7.63(2 \mathrm{H}, \mathrm{d}, J$ $\left.=5.8 \mathrm{~Hz}, \mathrm{H}-14,1^{\prime}\right), 6.61(1 \mathrm{H}, \mathrm{s}, \mathrm{H}-4), 4.97(2 \mathrm{H}, \mathrm{s}, \mathrm{H}-16), 4.37(2 \mathrm{H}, \mathrm{s}, \mathrm{H}-11), 4.35(1 \mathrm{H}, \mathrm{m}, \mathrm{H}-8), 2.97(4 \mathrm{H}$, $\left.\mathrm{m}, \mathrm{H}-17,17^{\prime}\right), 1.77\left(4 \mathrm{H}, \mathrm{m}, \mathrm{H}-18,18^{\prime}\right), 1.36(2 \mathrm{H}, \mathrm{m}, \mathrm{H}-19), 1.29(6 \mathrm{H}, \mathrm{d}, \mathrm{J}=6.7 \mathrm{~Hz}, \mathrm{H}-9,10) .{ }^{13} \mathrm{C}-\mathrm{NMR}$ for the isomer of $7\left(100 \mathrm{MHz}, \mathrm{C}_{5} \mathrm{D}_{5} \mathrm{~N}\right) \delta: 211.2(\mathrm{C}-7), 166.4(\mathrm{C}-1), 164.6(\mathrm{C}-3), 162.5(\mathrm{C}-5), 145.2(\mathrm{C}-12)$, $132.23\left(\mathrm{C}-14,14^{\prime}\right), 130.3\left(\mathrm{C}-13,13^{\prime}\right), 128.04$ (C-15), 107.5 (C-6), 104.8 (C-2), 95.9 (C-4), 64.3 (C-16), 53.25 $\left(\mathrm{C}-17,17^{\prime}\right), 39.7$ (C-8), 29.2 (C-11), 23.84 (C-18, 18'), 23.01 (C-19), 20.3 (C-9, 10).

\subsection{Assay for iNOS Inhibition}

The assay was performed in mouse macrophages (RAW264.7, obtained from ATCC)) cultured in phenol red free RPMI medium supplemented with $10 \%$ bovine calf serum and $100 \mathrm{U} / \mathrm{mL}$ penicillin G sodium, and $100 \mu \mathrm{g} / \mathrm{mL}$ streptomycin at $37{ }^{\circ} \mathrm{C}$ in an atmosphere of $5 \% \mathrm{CO}_{2}$ and $95 \%$ humidity. Cells were seeded in 96-well plates (50,000 cells/well) and incubated for $24 \mathrm{~h}$ for a confluency of 75\% or more. Test samples diluted in serum free medium were added, and after 30 min of incubation, LPS $(5 \mu \mathrm{g} / \mathrm{mL})$ was added and cells were further incubated for $24 \mathrm{~h}$. The concentration of nitric oxide (NO) was determined by measuring the level of nitrite in the cell culture supernatant by using Griess reagent. Percent inhibition of nitrite production by the test compound was calculated in comparison to the vehicle control. $\mathrm{IC}_{50}$ values were obtained from concentration response curves. Parthenolide was used as a positive control [25].

\subsection{Assay for NF- $\kappa B$ Inhibition}

The assay was performed in human chondrosarcoma cells (SW1353, obtained from American Type Culture Collection (ATCC), Manassas, VA, USA). Cells were cultured in 1:1 mixture of DMEM/F12 supplemented with $10 \%$ fetal bovine serum (FBS), $100 \mathrm{U} / \mathrm{mL}$ penicillin G sodium, and $100 \mu \mathrm{g} / \mathrm{mL}$ streptomycin at $37^{\circ} \mathrm{C}$ in an atmosphere of $5 \% \mathrm{CO}_{2}$ and $95 \%$ humidity. Cells $\left(1.2 \times 10^{7}\right)$ were washed once in an antibiotic and FBS-free DMEM/F12, and then resuspended in $500 \mu \mathrm{L}$ of antibiotic-free $\mathrm{DMEM} / \mathrm{F} 12$ containing $2.5 \%$ FBS. NF- $\mathrm{KB}$ luciferase plasmid construct was added to the cell suspension at a concentration of $50 \mu \mathrm{g} / \mathrm{mL}$ and incubated for $5 \mathrm{~min}$ at room temperature. The cells were electroporated at $160 \mathrm{~V}$ and one 70-ms pulse using BTX disposable cuvettes model 640 (4-mm gap) in a BTX Electro Square Porator T 820 (BTX I, San Diego, CA, USA). The transfected cells were plated to the wells of 96-well plates at a density of $1.25 \times 10^{5}$ cells per well. After $24 \mathrm{~h}$, cells were treated with different concentrations of test compound for $30 \mathrm{~min}$ before the addition of PMA $(70 \mathrm{ng} / \mathrm{mL})$ and incubated for $8 \mathrm{~h}$. Luciferase activity was measured using the Luciferase Assay kit (Promega). Light output was detected on a SpectraMax plate reader. Percent inhibition of luciferase activity was calculated as compared to vehicle control, and $\mathrm{IC}_{50}$ values were obtained from concentration response curves. Parthenolide was used as positive control [25].

\subsection{Cytotoxicity Assay}

Cytotoxicity was determined against the mammalian cell line Vero (African green monkey kidney fibroblast) which was obtained from ATCC. The detailed assay procedure has been described previously [26]. In brief, cells were seeded in 96-well plates (10,000 cells /well), and after $24 \mathrm{~h}$ of incubation, they were treated with various dilutions of test samples for $48 \mathrm{~h}$. The cell viability was determined by tetrazolium dye WST-8. Doxorubicin was included as drug control.

Supplementary Materials: The following are available online. Supplementary Materials, including MS, HRMS, 1D and 2D NMR spectra for the synthetic compounds, are available online. 
Author Contributions: N.L.: chemical synthesis, data analysis and manuscript preparation; S.I.K.: bioassay and interpretation of data and manuscript editing; S.Q.: NMR analysis; X.-C.L.: project design and manuscript preparation.

Funding: This work was supported by the USDA Agricultural Research Service Specific Cooperative Agreement No. 58-6060-6-015.

Conflicts of Interest: The authors declare no conflict of interest.

\section{References}

1. Singh, I.P.; Sidana, J.; Bharate, S.B.; Foley, W.J. Phloroglucinol compounds of natural origin: Synthetic aspects. Nat. Prod. Rep. 2010, 27, 393-416. [CrossRef] [PubMed]

2. Schmidt, S.; Jurgenliemk, G.; Schmidt, T.J.; Skaltsa, H.; Heilmann, J. Bi-, tri-, and polycyclic acylphloroglucinols from Hypericum empetrifolium. J. Nat. Prod. 2012, 75, 1697-1705. [CrossRef] [PubMed]

3. Song, C.K.; Zhao, S.; Hong, X.T.; Liu, J.Y.; Schulenburg, K.; Schwab, W. A UDP-glucosyltransferase functions in both acylphloroglucinol glucoside and anthocyanin biosynthesis in strawberry (Fragaria $\times$ ananassa). Plant J. 2016, 85, 730-742. [CrossRef] [PubMed]

4. Zhao, J.; Liu, W.; Wang, J.C. Recent advances regarding constituents and bioactivities of plants from the genus Hypericum. Chem. Biodivers. 2015, 12, 309-349. [CrossRef] [PubMed]

5. Tanaka, N.; Kobayashi, J. Prenylated acylphloroglucinols and meroterpenoids from Hypericum plants. Heterocycles 2015, 90, 23-40.

6. Henry, G.E.; Campbell, M.S.; Zelinsky, A.A.; Liu, Y.B.; Bowen-Forbes, C.S.; Li, L.Y.; Nair, M.G.; Rowley, D.C.; Seeram, N.P. Bioactive Acylphloroglucinols from Hypericum densiflorum. Phytother. Res. 2009, 23, 1759-1762. [CrossRef] [PubMed]

7. Tanaka, N.; Tsuji, E.; Kashiwad, Y.; Kobayashi, J.I. Yezo'otogirins D-H, Acylphloroglucinols and meroterpenes from Hypericum yezoense. Chem. Pharm. Bull. 2016, 64, 991-995. [CrossRef]

8. Kondo, A.; Shimizu, K. Spanate (flopropione), its clinical evaluation for urolithiasis and effects on ureteral peristalsis and blood pressure in dogs. Hinyokika Kiyo. 1969, 15, 748-754.

9. Fukuyama, T.; Takahashi, Y.; Kuze, M.; Arai, E. Clinical experiences with spanate, a new antispasmodic. Hinyokika Kiyo. 1969, 15, 818-823.

10. Jung, H.A.; Jin, S.E.; Ahn, B.R.; Lee, C.M.; Choi, J.S. Anti-inflammatory activity of edible brown alga Eisenia bicyclis and its constituents fucosterol and phlorotannins in LPS-stimulated RAW264.7 macrophages. Food Chem. Toxicol. 2013, 59, 199-206. [CrossRef]

11. Lopes, G.; Sousa, C.; Silva, L.R.; Pinto, E.; Andrade, P.B.; Bernardo, J.; Mouga, T.; Valentão, P. Can phlorotannins purified extracts constitute a novel pharmacological alternative for microbial infections with associated inflammatory conditions? PLOS ONE 2012, 7. [CrossRef] [PubMed]

12. Koeberle, A.; Rossi, A.; Bauer, J.; Dehm, F.; Verotta, L.; Northoff, H.; Sautebin, L.; Werz, O. Hyperforin, an anti-Inflammatory constituent from St. John's Wort, inhibits microsomal prostaglandin E(2) synthase-1 and suppresses prostaglandin E(2) formation in vivo. Front Pharmacol. 2011, 2, 1-10. [CrossRef] [PubMed]

13. Shaari, K.; Suppaiah, V.; Wai, L.K.; Stanslas, J.; Tejo, B.A.; Israf, D.A.; Abas, F.; Ismail, I.S.; Shuaib, N.H.; Zareen, S.; Lajis, N.H. Bioassay-guided identification of an anti-inflammatory prenylated acylphloroglucinol from Melicope ptelefolia and molecular insights into its interaction with 5-lipoxygenase. Bioorga. Med. Chem. 2011, 19, 6340-6347. [CrossRef] [PubMed]

14. Veena, V.K.; Popavath, R.N.; Kennedy, K.; Sakthivel, N. In vitro antiproliferative, pro-apoptotic, antimetastatic and anti-inflammatory potential of 2,4-diacteylphloroglucinol (DAPG) by Pseudomonas aeruginosa strain FP10. Apoptosis 2015, 20, 1281-1295. [CrossRef] [PubMed]

15. Zhou, K.; Ludwig, L.; Li, S.M. Friedel-Crafts Alkylation of Acylphloroglucinols catalyzed by a fungal indole prenyltransferase. J. Nat. Prod. 2015, 78, 929-933. [CrossRef] [PubMed]

16. Zhu, H.C.; Chen, C.M.; Liu, J.J.; Sun, B.; Wei, G.Z.; Li, Y.; Zhang, J.W.; Yao, G.M.; Luo, Z.W.; Xue, Y.B.; Zhang, Y.H. Hyperascyrones A-H, polyprenylated spirocyclic acylphloroglucinol derivatives from Hypericum ascyron Linn. Phytochemistry 2015, 115, 222-230. [CrossRef] [PubMed]

17. Yu, Q.; Ravu, R.R.; Jacob, M.R.; Khan, S.I.; Agarwal, A.K.; Yu, B.Y.; Li, X.C. Synthesis of natural acylphloroglucinol-based antifungal compounds against Cryptococcus species. J. Nat. Prod. 2016, 79, 2195-2201. [CrossRef] 
18. George, J.H.; Hesse, M.D.; Baldwin, E.; Adlington, R.M. Biomimetic synthesis of polycyclic polyprenylated acylphloroglucinol natural products isolated from Hypericum papuanum. Org. Lett. 2010, 12, 3532-3535. [CrossRef]

19. Pepper, H.P.; Lam, H.C.; Bloch, W.M.; George, J.H. Biomimetic total synthesis of ( \pm )-Garcibracteatone. Org. Lett. 2012, 14, 5162-5164. [CrossRef]

20. Morkunas, M.; Dube, L.; Gotz, F.; Maier, M.E. Synthesis of the acylphloroglucinols rhodomyrtone and rhodomyrtosone B. Tetrahedron 2013, 69, 8559-8563. [CrossRef]

21. Liu, X.H.; Zhai, Z.W.; Xu, X.Y.; Yang, M.Y.; Sun, Z.H.; Weng, J.Q.; Tan, C.X.; Chen, J. Facile and efficient synthesis and herbicidal activity determination of novel 1,2,4-triazolo[4,3-a]pyridin-3(2H)-one derivatives via microwave irradiation. Bioorg. Med. Chem. Lett. 2015, 25, 5524-5528. [CrossRef]

22. Shen, Z.H.; Sun, Z.H.; Becnel, J.J.; Estep, A.; Wedge, D.E.; Tan, C.X.; Weng, J.Q.; Han, L.; Liu, X.H. Synthesis and mosquiticidal activity of novel hydrazone containing pyrimidine derivatives against Aedes aegypti. Lett. Drug Des. Discov. 2018, 15, 951-956. [CrossRef]

23. Zhang, L.J.; Yang, M.Y.; Sun, Z.H.; Tan, C.X.; Weng, J.Q.; Wu, H.K.; Liu, X.H. Synthesis and antifungal activity of 1,3,4-thiadiazole derivatives containing pyridine group. Lett. Drug Des. Discov. 2014, 11, 1107-1111. [CrossRef]

24. Kleinschek, M.A.; Muller, U.; Brodie, S.J.; Stenzel, W.; Kohler, G.; Blumenschein, W.M.; Straubinger, R.K.; McClanahan, T.; Kastelein, R.A.; Alber, G. IL-23 enhances the inflammatory cell response in Cryptococcus neoformans infection and induce a cytokine pattern distinct from IL-12. J. Immunol. 2006, 176, 1098-1106. [CrossRef]

25. Zhao, J.P.; Khan, S.I.; Wang, M.; Vasquez, Y.; Yang, M.H.; Avula, B.; Wang, Y.H.; Avonto, C.; Smillie, T.J.; Khan, I.A. Octulosonic acid derivatives from Roman chamomile (Chamaemelum nobile) with activities against inflammation and metabolic disorder. J. Nat. Prod. 2014, 77, 509-515. [CrossRef]

26. Zulfiqar, F.; Khan, S.I.; Rossa, S.A.; Ali, Z.; Khan, I.A. Prenylated flavonol glycosides from Epimedium grandiflorum: Cytotoxicity and evaluation against inflammation and metabolic disorder. Phytochem. Lett. 2017, 20, 160-167. [CrossRef]

Sample Availability: Samples of the compounds are not available.

(c) 2018 by the authors. Licensee MDPI, Basel, Switzerland. This article is an open access article distributed under the terms and conditions of the Creative Commons Attribution (CC BY) license (http://creativecommons.org/licenses/by/4.0/). 